Original Research Paper

\title{
Integrasi Taman Herbal Dengan Lebah Madu Trigona Sp. di Desa Sesela Lombok Barat Sebagai Nutrisi Tambahan Di Masa Pandemi Covid-19
}

\author{
Ni Made Andry Kartika ${ }^{1 *}$, Yuni Mariani ${ }^{1}$, Lale Yaqutunnafis ${ }^{2}$, Baiq Salkiah², Farman Andi \\ Triwidardi ${ }^{3}$ \\ ${ }^{1}$ Fakultas Peternakan, Universitas Nahdlatul Wathan Mataram, Nusa Tenggara Barat, Indonesia; \\ ${ }^{2}$ Fakultas Keguruan dan Ilmu Pendidikan, Universitas Nahdlatul Wathan Mataram,Nusa \\ Tenggara Barat, Indonesia; \\ ${ }^{3}$ Fakultas Hukum, Universitas Nahdlatul Wathan Mataram, Nusa Tenggara Barat, Indonesia;
}

https://doi.org/10.29303/jpmpi.v3i2.1029

Sitasi: Kartika, N. M. A., Mariani, Y., Yaqutunnafis, L., Salkiah, B \& Triwidaridi, F. A. (2021). Integrasi Taman Herbal Dengan Lebah Madu Trigona Sp. di Desa Sesela Lombok Barat Sebagai Nutrisi Tambahan Di Masa Pandemi Covid-19. Jurnal Pengabdian Magister Pendidikan IPA, 4(4)

\section{Article history}

Received: 20 September 2021

Revised: 30 September 2021

Accepted: 10 Oktober 2021

*Corresponding Author: Ni

Made Andry Kartika,

Fakultas Peternakan,

Universitas Nahdlatul Wathan

Mataram, Nusa Tenggara

Barat, Indonesia;

Email:

d0814109001@unwmataram.ac.id

\begin{abstract}
Abstrak: Kegiatan ini bertujuan untuk memanfaatkan pekarangan disekitar desa Sesele dengan menanam tanaman herbal yang dapat dimanfaatkan oleh warga sebagai pemenuhan kebutuhan dalam menunjang kesehatan seperti membuat jamu dll. Taman herbal ini diintegrasikan dengan budidaya lebah madu Trigona sp. supaya lebih optimal pemanfaatannya. Metode yang digunakan adalah sosialisasi dan praktek langsung di Desa Sesela Kecamatan Gunung Sari Kabupaten Lombok Barat. Hasil kegiatan menunjakan bahwa ada respon positif dari prangkat desa dan masyarakat di wilayah desa sesela dalam mengaplikasikan anatara tanaman herbal/obat dengan lebah madu Trigona sp. setelah dilakukan sosialisasi perangkat desa dan masyarakat juga mengetahui nilai ekonomis dari hasil integrasi ini patut dijadikan sumber pendapatan tambahan di masa pandemi.
\end{abstract}

Keywords: Tanaman herbal, Lebah madu Trigona sp, Desa Sesela

\section{Pendahuluan}

Perkembangan pandemi covid-19 yang hampir dua tahun menerpa Dunia dan Indonesia mengakibatkan mulai terbentuk tatanan kehidupan baru di masyarakat. Akibat pandemi yang terjadi selama ini masyarakat mulai menerapkan gaya hidup sehat di seluruh lini kehidupan. Mulai dari anak - anak hingga orang tua sudah mulai paham standar pencegahan yang harus dilakukan agar tidak terpapar covid-19. Indonesia memiliki keanekaragam hayati yang sangat lengkap. Hal ini membuat Indonesia menjadi Negara pengobatan herbal terbaik di dunia. Beragam jenis tanaman obat dapat tumbuh dengan subur di Negara ini. Tanaman obat menjadi bahan utama dalam pembuatan jamu dan obat - obatan herbal (Savitri,2016).

Pemanfaatan tanaman herbal semakin gencar belakangan ini, pandemic covid-19 mengakibatkan masyarakat mulai membuat dan mengkonsumsi ramuan - ramuan tradisional warisan leluhur. Rostiyati (2012) Hakekatnya pengobatan tradisional di Indonesia merupakan bagian kebudayaan bangsa Indonesia yang diturunkan dari generasi kegenerasi berikutnya secara lisan atau tulisan. Karena itu kepercayaan terhadap obat tradisional di Indonesia dapat terus bertahan, walaupun praktek-praktek biomedik kedokteran mengalami perkembangan.

Selain tanaman herbal, sumber lain yang juga menjadi alternative suplemen bagi kesehatan adalah madu. Madu merupakan campuran dari gula, 
antioksidan, vitamin dll yang dihasilkan dari Lebah. Salah satu jenis lebah yang banyak dibudidayakan di rumah - rumah warga saat ini adalah Lebah Trigona Sp. Lebah ini memiliki keunggulan anatra lain tidak bersengat, memiliki rasa madu yang khas sedikit asam akibat tingginya antioksidan dan harga jualnya lebih mahal disbanding madu lainnya (Rosyiadi, et.al., 2018).

Lebah madu Trigona yang dipelihara tentunya membutuhkan pakan yang bersumber dari tanaman bunga, kelapa dan buah - buahan. Di masa pandemi ini pemanfaatan tanaman herban meningkat bersamaan dengan konsumsi madu juga yang semakin meningkat. Di Desa Sesela Lombok Barat beberapa mahasiswa yang telah melakukan program pengabdian dalam bentuk Kuliah Kerja Nyata (KKN) melakukan percobaan dengan mengintegrasikan antara taman herbal dan budidaya Lebah Trigona Sp. Dengan teknik integrasi taman herbal dan budidaya lebah madu ini diharapkan menjadi salah satu upaya dalam meningkatkan sumber ketersedian bahan rempah - rempah/jamu

\begin{tabular}{|c|c|c|c|c|}
\hline No & Metode & Kegiatan & Dokumentasi & Keterangan \\
\hline 1 & $\begin{array}{l}\text { Menyiapakan } \\
\text { alat dan bahan }\end{array}$ & $\begin{array}{l}\text { Menyiapkan dan } \\
\text { membersihan lahan } \\
\text { yang akan } \\
\text { digunakan menjadi } \\
\text { taman herbal/taman } \\
\text { obat. }\end{array}$ & 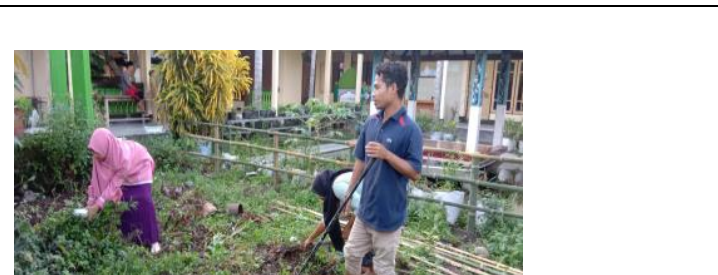 & $\begin{array}{l}\text { Diikuti oleh } \\
\text { semua aggota }\end{array}$ \\
\hline & & & $\begin{array}{l}\text { Gambar } 1 \& 2 \text { membersihan lahan yang } \\
\text { diguankan untuk membuat taman herbal/obat }\end{array}$ & \\
\hline 2 & $\begin{array}{l}\text { Peroses } \\
\text { penaman }\end{array}$ & $\begin{array}{l}\text { Dilakukan } \\
\text { penanaman tanaman } \\
\text { obat pada lahan } \\
\text { yang } \\
\text { dibersihan. } \\
\text { Selanjutnya setelah } \\
\text { diatanam diberikan } \\
\text { pupuk kandang dan } \\
\text { dilakukan } \\
\text { penyiraman setiap } \\
\text { harinya. }\end{array}$ & $-\ln 1$ & $\begin{array}{l}\text { Semua } \\
\text { anggota dan } \\
\text { staf desa }\end{array}$ \\
\hline
\end{tabular}

dan madu kualitas tinggi yang harapannya dapat menjaga daya tahan tubuh dari serangan virus dan bakteri.

\section{Metode}

\section{a. Lokasi}

Pengabdian ini dilakukan di Kantor Desa Sesela Kabupaten Lombok Barat. Program ini dilakukan oleh Mahasiswa KKN UNW Mataram dari bulan Agustus - September 2021.

\section{b. Materi}

Adapun materi yang disiapkan anatra lain Tanaman Herbal dan Lebah Madu Trigona Sp. Tanaman herbal terdiri dari ; kunyit, jahe, lengkuas, tamulawak, kumis kucing, daun kemangi, stoberi 20 pohon di polibek, serae, daun kayu manis, daun pandan, pohon papaya, tanaman bunga dll. Peralatan yang digunakan anatra lain; cangkul, gareng, sekop, bambu, paku, palu geregaji, linggis.

\section{c. Langkah kerja}




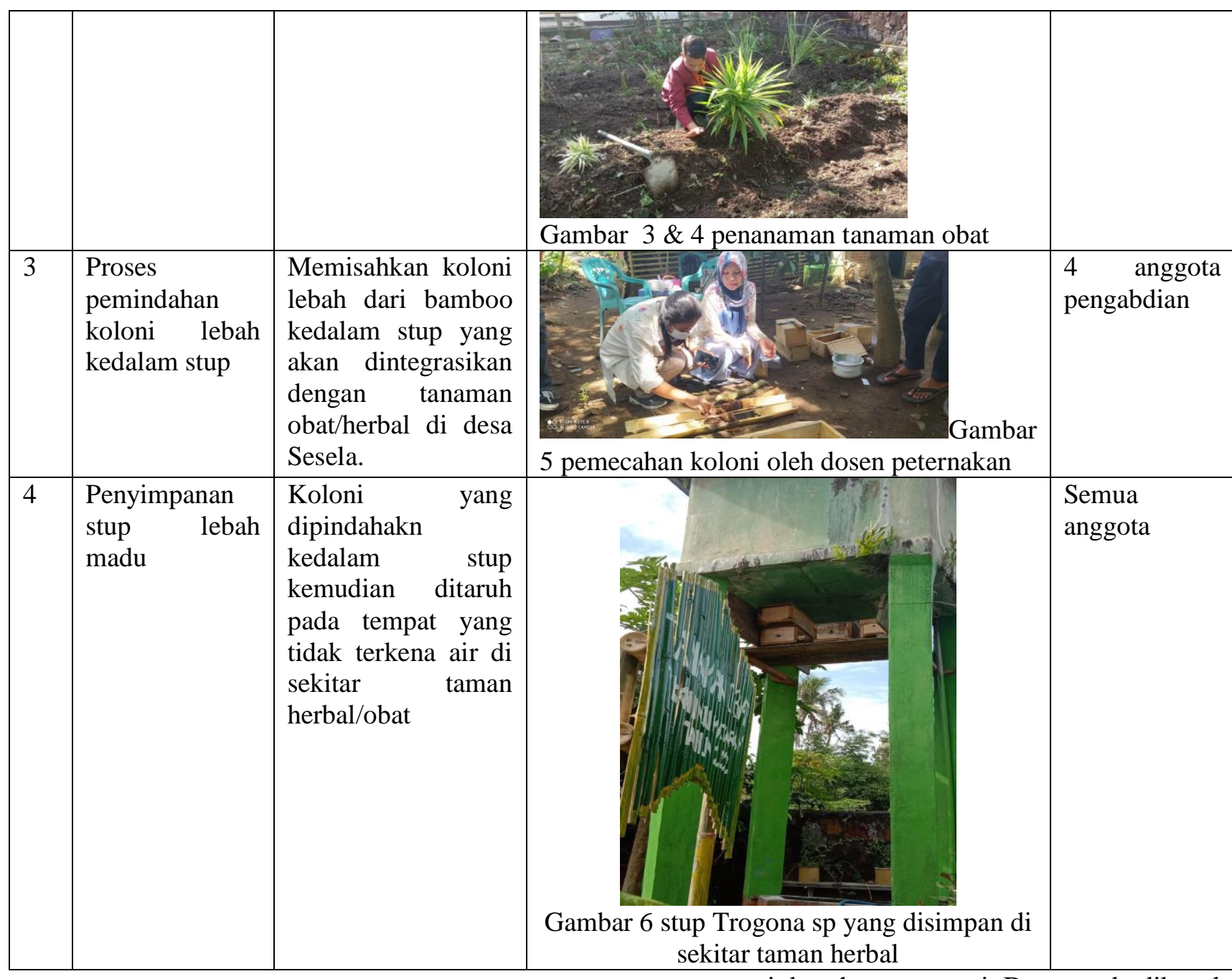

\section{Hasil dan Pembahasan}

\section{a. Profil Desa Sesela}

Desa Sesela termasuk dalam Kecamatan Gunungsari diwilayah kerja Kabupaten Lombok Barat. Sesela memiliki 11 Dusun dimana sebagian besar masyarakatnya bermata pencaharian sebagai pedagang. selain itu Sesela juga terkenal sebagai salah satu sentra usaha kerajinan ukir-ukiran di wilayah Lombok Barat. Luas desa Sesela adalah 227.27 Ha, dengan batas desa terdiri dari sebelah barat berbatasan dengan Desa Jatisela, sebelah timur berbatasan dengan Desa Midang, sebelah utara Sungai Meninting, dan sebelah selatan Sungai Midang.

Desa Sesela merupakan desa dengan keragaman, hal ini dikarekanan banyak terdapat perumahan berupa BTN yang tersebar di wilayah ini. Mata pencaharian di desa sesela beragam, mulai dari pedagang, pengerajin, pegawai, buruh serta petani. Desa sesela dikenal dengan kerajinan anyaman bambunya yang khas. Hal ini bias dilihat disepanjang jalan desa sesela yang memajang hasil kerajinan tersebut.

Sebagai salah satu desa penyanggah yang berbatasan langsung dekan ibu kota provinsi yaitu Kota Mataram, mengakibatkan desa sesala tampak sangat berkembang dan memiliki masalah dan kemajuan yang hampir sama dengan wilayah perkotaan pada umumnya.

b. Integrasi Tanaman Herbal dengan Budidaya

\section{Lebah Madu}

Salah satu program pengabdian yang dilakukan oleh dosen dan mahasiswa UNW Mataram di Desa Sesela dalam rangka pencegahan covid-19 adalah mengajak dan membuat percontohan taman herbal yang diintegrasikan dengan lebah madu jenis Trigona $s p$.

Integrasi merupakan kombinasi antara dua hal yang berbeda tetapi dapat mendatangkan 
manfaat pada akhirnya. Integrasi antara tanaman herbal dan lebah madu ini ditempatkan pada kantor desa sebagai percontohan karena di kantor desa dijadikan ajak promosi yang terus menerus, makdudnya adalah pada umumnya setiap hari kantor desa akan didatangi oleh berbagai pihak yang memiliki kepentingan seperti pejabat terkait, masyarakat atau pihak swasta/investor.

Kegiatan ini bertujuan untuk memanfaatkan pekarangan disekitar desa Sesele dengan menanam tanaman herbal yang dapat dimanfaatkan oleh warga sebagai pemenuhan kebutuhan dalam menunjang kesehatan seperti membuat jamu dll. Taman herbal ini diintegrasikan dengan budidaya lebah madu trigona supaya lebih optimal pemanfaatannya.

Tanaman herbal atau tanaman obat dalam kegiatan ini terdapat beberapa jenis tanaman yang ditanam yaitu kunyit, jahe, kencur, bidara, kumis kucing,temulawak, kemangi, sereh, lengkuas, daun kayu manis, papaya, dll. Semua tanaman tersebut merupakan semua jenis tanaman yang memiliki manfaat dibidang kesehatan. Setelah melakukan penanaman, dilakukan perawatan tanaman dengan cara : 1) penyiraman, 2) pemupukan dengan pupuk organik, dan 3) penyiangan.

Tanaman obat banyak digunakan sebagai bahan baku obat tradisional dan jamu, yang apabila dikonsumsi dapat meningkatkan kekebalan tubuh (immune system), karena tanaman ini mempunyai sifat spesifik sebagai tanaman obat yang bersifat pencegahan (preventif) dan promotif melalui kandungan metabolit sekunder contohnya seperti gingiro pada jahe dan santoriso pada temulawak yang mampu meningkatkan sistem kekebalan tubuh. Jamu tidak dapat menyembuh kan yaitu bersifat kuratif, namun lebih kearah sebagai pencegahan dengan cara meningkatkan kekebalan tubuh, sehingga lebih bermanfaat untuk mencegah COVID-19 (Reza Pertiwi et.al 2020).

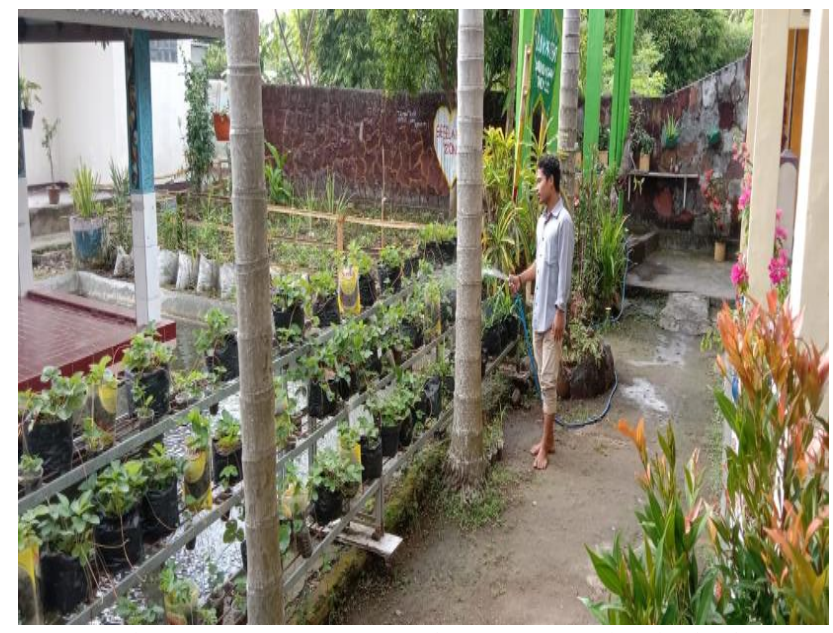

Gambar 7 Perawatan pada tanaman herbal/obat yang telah di tanam

Tanaman herbal ini nantinya bisa dimanfaatkan oleh lebah madu trigona sp.sebagai salah satu sumber pakan yaitu dengan memanfaatkan nektar dan polen yang dihasilkan oleh tanaman tersebut. Lebah Madu Trigona merupakan jenis Lebah Madu tak bersengat (stingles honey bees) yang dapat ditemukan di wilayah yang beriklim tropis dan beberapa daerah beriklim subtropics (Michener, 2007). Lebah Madu Trigona (Trigona) beluin banyaL dikenal oleh masyarakat di Indonesia, karena kurangnya informasi tentang lebah tersebut. Lebah Madu Trigona dikenal dengan nama lokal seperti lebah klenceng (Jawa), gala-gala dan teuweul (Sunda).

Budidaya lebah madu trigona dalam kegiatan ini dilakukan dengan system pecah koloni pada stup modern yang terbuat dari dari kayu dibentuk seperti kotak. Pecah koloni dilakukan dengan cara memindahkan sebagian koloni dari stup yang sudah ada koloninya. Hal yang pertama dilakukan menyiapan stup kosong dan menyiapkan stup lama yang sudah dibudidayakan sebelumnya yang didalamnya terdiri dari lebah ratu, jantan, dan betina. Pecah koloni ini bertujuan untuk memeperbanyak koloni yang dibudayakan. Stup baru ini berisi telur ratu, lebah jantan dan lebah betina yang siap untuk dibudidayakan. 


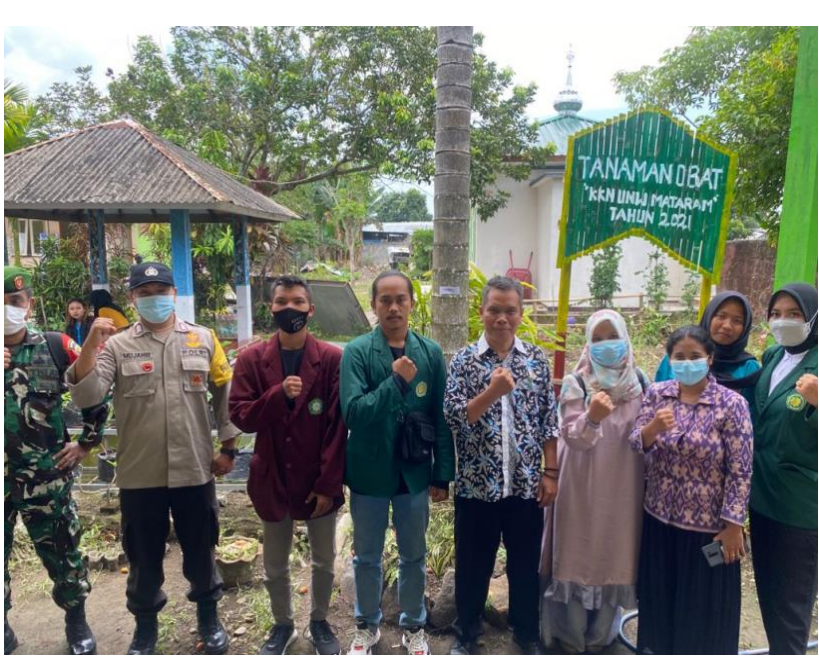

Gambar 8 Foto anggota pengabdian dan babinsa serta staf desa sesela

Produk yang dihasilkan lebah yang bisa dimanfaatkan sebagai kesehatan berupa madu, polen, bee bread, royal jeli, propolis dan lilin lebah.Produk-produk tersebut memberi kan keuntungan secara ekonomis untuk peternak dan kesehatan untuk konsumen. Hasil dari produk lebah banyak dikonsumsi untuk menjaga kesehatan manusia. Salah satu produk yang banyak dijual selain madu, memiliki khasiat yang baik untuk tubuh dan harga yang tinggi adalah propolis. Propolis merupakan suatu produk yang dihasilkan oleh lebah madu dan mengandung resin dan lilin lebah yang dikumpulkan dari sumber tanaman. Propolis dikumpulkan oleh lebah dari pucuk daundaun yang muda untuk kemudian dicampur dengan air liur nya digunakan untuk menambal dan mensterilkan sarang. Kandungan dari propolis merupakan senyawa alami yang dikoleksi oleh lebah madu yang berasal dari kuncup dan eksudat tanaman dan pepohonan (Segueni et al., 2011). Propolis banyak digunakan sebagai salah satu alternative pengobatan alami pada saat ini. Komponen yang terkandung di dalamnya merupakan senyawa bioaktif yang dapa tmemberikan efek positif pada tubuh.Harga propolis yang cukup tinggi dan memiliki khasiat yang baik untuk manusia menjadikannya salah satu produk yang memberikan keuntungan untuk peternak.Senyawa bioaktif pada propolis kaya akan flavonoid danfenoliknya (Segueni et al., 2011). Senyawa tersebut merupakan antioksidan yang dapat digunakan untuk melawan radikal bebas. Kandungan senyawa fenolik dan flavonoid propolis tergantung dari letak geografis dan jenis lebah tersebut (Chan et al., 2013).

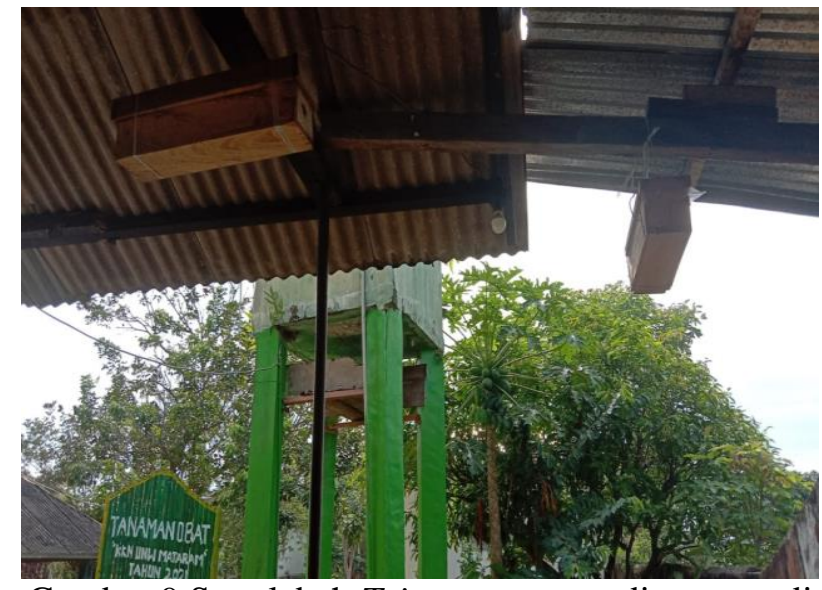

Gambar 9 Stup lebah Trigona sp yang digantung di dekat tanaman obat

\section{c. Analisis Ekonomi}

Lebah madu yang disimpan di Desa Sesela ini rencananya akan dipanen dalam 3 bulan sekali. Dari segi ekonomi madu Trigona sp memiliki harga jual lebih tinggi dibandingkan dengan madu lainnya. Untuk $500 \mathrm{ml}$ madu Trigona $s p$ harga dipasaran adalah Rp.250.000 - 300.000, sementra madu melifera dan dorsata harganya sekitar Rp.100.000-150.000,- ribu. Perbedaan harga jual ini menjadi potensi yang menarik untuk dapat dikembangkan di Desa Sesela Kecamatan Gunung Sari Lombok Barat. Integrasi antara tanaman obat dan lebah ini diharapkan menjadi bukti nyata yang dapat dilihat masyarakat sekitar sebagai salah satu alternatif pendapatan di masa pandemi ini.

\section{Kesimpulan}

Dari pembahasan di atas dapat disimpulkan beberapa hal penting sebagai berikut; Tanaman obat/herbal yang ditanam dapat dimanfaatkan sebagai sumber pengobatan alternatif sebagai pencegahan covid-19. Integrasi antara tanaman herbal dan lebah madu Trigona $s p$ bermanfaat sebagai salah satu sumber pakan yaitu dengan memanfaatkan nektar dan polen yang dihasilkan oleh tanaman tersebut, sehingga hasil madunya nanti akan mengandung bahan yang baik bagi kesehatan tubuh.

\section{Ucapan Terima Kasih}

Kami keluarga besar dosen UNW dan Mahasiswa KKN Desa Sesela Kecamatan Gunung Sari Kabupaten Lombok Barat mengucapkan terimakasih kepada LPPM UNW Mataram dan 
Desa Sesela yang telah membantu dalam penyelesaian artikel ini.

\section{Daftar Pustaka}

Chan, G. C.-F., Cheung, K.-W., \& Sze, D. M.-Y. (2013). The immunomodulatory \& anticancer properties of propolis. Clinical Reviews in Allergy \& Immunology, 44(3), 262-273. https://doi.org/10.1007/s12016-012-8322-2 Michener, C. D. 2007. The Bees of The World. The Johns Hopkins University Press, Maryland (US).

Pertiwi, Reza., Doni Natriawan, Risky Hadi Wibowo. 2020. Pemanfaatan Tanaman Obat

Keluarga (TOGA) Meningkatkan Imunitas Tubuh sebagai pencegahan Covid-19. https://ejournal.unib.ac.id/index.php/dharm araflesia/article/view/12665/6842

Rosyiadi, Djalal. Lilik Eka Radiati, Sri Minarti, Mustakim, Agus Susilo, Firman Jaya dan Abdul

Azis. 2018. Perbandingan Sifat Antioksidan Propolis Pada Dua Jenis Lebah (Apis mellifera dan Trigona sp.) Di Mojokerto Dan Batu, Jawa Timur, Indonesia. Jurnal Ilmu dan Teknologi Hasil Ternak, Vol.13. No.2 diterbitkan Oktober 2018, Hal 108-117. https://jitek.ub.ac.id/index.php/jitek/article/ view/331/282

Rostiyati, Ani. (2012). Sistem Pengobatan Tradisional Kasus di Desa Girijaya Sukabumi. Bandung: PT. Wacana Gelora Cipta.

Savitri A. (2016). Tanaman Ajaib Basmi Penyakit Dengan Toga (tanaman obat keluarga).

Halaman 6 jakarta utara. Bibit Publisher.

Segueni, N., Zellagui, A., Moussaoui, F., Lahouel, M., \& Rhouati, S. (2016). Flavonoids from

Algerian propolis. Arabian Journal of Chemistry, 9(1), 425-428. https://doi.org/10.1016/J.ARABJC.2011.05 .013 